\title{
Regulation of Brain-derived Neurotrophic Factor (BDNF) Expression and Release from Hippocampal Neurons Is Mediated by Non-NMDA Type Glutamate Receptors
}

\author{
Cynthia Wetmore, Lars Olson, and Andrew J. Bean \\ Department of Histology and Neurobiology, Karolinska Institute, 10401 Stockholm, Sweden
}

\begin{abstract}
We have examined the influence of glutamate on cortical brain-derived neurotrophic factor (BDNF) expression using in situ hybridization and immunohistochemistry. Kainic acid (KA) produced an upregulation of hippocampal and neocortical BDNF mRNA as well as BDNF protein that was blocked by a non-NMDA antagonist, 6,7-dinitroquinoxaline-2,3-dione (DNQX), but was not affected by the NMDA antagonist 2-amino-7-phosphonoheptanoic acid (AP7). Basal levels of BDNF mRNA were not affected by NMDA, DNQX, or AP7 treatment. BDNF protein was also increased after kainate exposure with a spatial and temporal course distinct from that seen for the expression of BDNF mRNA. A dramatic shift in BDNF immunoreactivity (-IR) was observed from intracellular compartments to the neuropil surrounding $C A 3$ pyramidal cells $2-3 \mathrm{hr}$ after $K A$ exposure. This shift in localization of BDNF-IR suggests a constitutive release of BDNF at the level of the cell body and dendrites. Moreover, we have localized mRNAs for full-length and truncated trkB, to a coincident population of neurons and glia. These data suggest the neurons that produce BDNF also express components necessary for a biological response to the same neurotrophic factor. The present study also demonstrates increased BDNF-IR in the mossy fiber terminal zone of hippocampus after exposure to KA, as well as an increase in trkB mRNA, and provides evidence of local release of this neurotrophin into the surrounding neuropil where it would be available for local utilization. The synthesis and putative release of BDNF from somatic and/or dendritic sites within the hippocampus provide evidence of a potential autocrine or paracrine role for BDNF, and establish a local source of trophic support for the maintenance of synaptic plasticity and anatomic reorganization in the mature nervous system.
\end{abstract}

IKey words: neurotrophin, NGF, brain-derived neurotrophic factor, kainic acid, hippocampus, trkB, sprouting, epilepsy]

Received Feb. 26, 1993; revised Aug. 2, 1993; accepted Aug. 30, 1993.

This study was supported by the Swedish Medical Research Council and U.S. Public Health Service Grant AG 04418. C.W. was supported by the Life \& Health Insurance Medical Research Fund and Karolinska Institutes Fonder. A.J.B. was supported by The Pharmaceutical Manufactures Association Foundation and The Scottish Rite Schizophrenia Research Foundation. We thank Susanne Almström, Eva Lindqvist, and Karin Lundströmer for expert technical assistance; and Jerry Sedgewick and Elisabeth Elde for photographic assistance.

Correspondence should be addressed to Cynthia Wetmore, Department of Cell Biology and Neuroanatomy, University of Minnesota, 321 Church Street, Minneapolis, MN 55455.

Copyright $(c) 1994$ Society for Neuroscience $0270-6474 / 94 / 141688-13 \$ 05.00 / 0$
The role of neurotrophic factors in the development and maintenance of neuronal architecture has attracted a great deal of interest with the recent cloning of several members of the NGF family. The neurotrophin family members NGF, brain-derived neurotrophic factor (BDNF) (Leibrock et al., 1989), and neurotrophin-3 (NT3) (Ernfors et al., 1990a; Hohn et al., 1990; Kaisho et al., 1990; Maisonpierre et al., 1990; Rosenthal et al., 1990) are highly conserved and share greater than $50 \%$ primary sequence homology (for reviews, see Barde, 1990; Thoenen, 1991). These neurotrophins affect the survival and differentiation of overlapping yet distinct populations of central and peripheral neurons (Thoenen and Barde, 1980; Levi-Montalcini, 1987; Barde, 1989; Lindsay et al., 1991). Because of their effects upon populations of neurons in the CNS, it has been suggested that a lack of trophic factors may play a role in neurodegenerative diseases (Mattson, 1989; Wainer, 1989; Lindsay et al., 1991; Phillips et al., 1991). For example, neuronal degeneration caused by lesions of various cholinergic projections to the hippocampus can be somewhat ameliorated by the administration of NGF (Hefti, 1986; Williams et al., 1986; Koliatsos et al., 1990; Strömberg et al., 1990), suggesting that changes in the availability of target-derived trophic factors may play a role in the remodeling of CNS connections. BDNF has attracted considerable interest because it is the most widely distributed neurotrophin family member in the brain (Ernfors et al., 1990b; Hofer et al., 1990; Phillips et al., 1990; Wetmore et al., 1990) and has been reported to increase the survival and expression of the neurotransmitter phenotype of cholinergic as well as dopaminergic neurons (Alderson et al., 1990; Hyman et al., 1991; Knüsel et al., 1991). Additionally, it has been demonstrated that multiple seizure episodes as well as injury can effect anatomical as well as functional changes in neuronal connectivity including long-term potentiation, mossy fiber sprouting, and synaptic reorganization within the hippocampus (Cotman et al., 1984; Cotman, 1985; Sutula et al., 1989; Cavazos et al., 1991; see BenAri and Represa, 1990; Geddes et al., 1990). Such alterations may well also involve altered expression of neurotrophic factors (Patterson et al., 1992; see Gall, 1992).

Glutamate is the major excitatory amino acid transmitter utilized in the brain (Kandel et al., 1991). Effects of glutamate are mediated through at least three receptor subtypes that have been classified pharmacologically with respect to their most selective ligands: NMDA, kainate, and quisqualate or $\alpha$-amino3-hydroxy-5-methylisoxazole-4-propionic acid (AMPA) (Watkins and Evans, 1981; Watkins et al., 1990). Ligand binding autoradiography has shown that the highest density of NMDA binding sites in brain is found in CAl of the hippocampus 
(Monaghan et al., 1983), while lower densities have been reported in CA3 and in the mossy fiber termination zone (Berger and Ben-Ari, 1983; Monaghan et al., 1983; Represa et al., 1987) (for review, see Cotman et al., 1987). In contrast, the highest densities of kainate receptor binding are found in hippocampal regions that contain low NMDA receptor density, such as the stratum lucidum and the zone of mossy fiber termination. This high receptor density correlates with the extreme sensitivity of cells in these areas to kainic acid (KA) (Nadler et al., 1978). Moreover, mRNAs for subunits of non-NMDA receptors are most highly expressed in pyramidal cells in CA1-CA3 and granule cells of the dentate gyrus (Boulter et al., 1990). Thus, excitatory amino acid receptors comprise a heterogeneous group of proteins that provide a basis for variable and dynamic cellular responses to a common neurotransmitter (Cotman et al., 1987).

Excitatory amino acids may produce neurotoxic effects (Simon et al., 1984; Wieloch, 1985; Mattson, 1989; Choi, 1990), and their receptors are altered in some neurodegenerative diseases (Geddes et al., 1985; Greenamyre et al., 1985). However, stimulation of excitatory amino acid receptors may also play a modulatory role in the expression of trophic factor mRNA (Isackson et al., 1991; for review, see Gall, 1992), suggesting that excitatory amino acids may have both destructive and constructive effects on neuronal architecture. In this regard, treatment with intracerebral (Ballarín et al., 1991; Gall et al., 1991) as well as systemic (Zafra et al., 1990; Dugich-Djordjevic et al., 1992) glutamate analogs has been reported to upregulate levels of NGF and BDNF, but not NT3 mRNAs. Neuronal activity, particularly via excitatory amino acid receptors, results in a rapid induction of immediate-early genes (Cole et al., 1989) as well as inducing synaptic remodeling (Brooks et al., 1991; Geinisman et al., 1992) and sprouting (Geddes et al., 1985; Cornell-Bell et al., 1990). Additionally, limbic seizures produce hippocampal cell loss (Mattson, 1989; Choi, 1990) as well as increase levels of NGF (Gall and Isackson, 1989), and alter excitatory amino acid receptor expression (Gall et al., 1990; see Gall, 1992).

In the present study we have investigated the pharmacology of KA-induced alterations in cortical BDNF expression in vivo, and the tonic influence of glutamate on the basal expression of BDNF mRNA. The complementary use of in sit $u$ hybridization and immunohistochemical techniques has allowed us to examine the anatomical distribution of cells that are affected by these pharmacological manipulations and to determine which of these cells also may express mRNA for $\operatorname{trkB}$, a component of the BDNF receptor. Using anti-peptide antibodies specific for BDNF (Wetmore et al., 1991, 1992), we were able to determine whether alterations in BDNF mRNA resulted in concomitant changes in protein expression, and to demonstrate the putative local release of BDNF from neurons within hippocampal subfields after KA administration. These data suggest that, unlike the storage and release of neuropeptides, which are confined to axon terminals (Elde et al., 1978), the release of neurotrophic factors may occur directly from somatic and/or dendritic sites and may play a role in the maintenance of local circuitry within the hippocampus by autocrine as well as paracrine mechanisms of action.

\section{Materials and Methods}

Compounds. KA (Sigma) was dissolved in saline (12 mg/ml), 2-amino7-phosphonoheptanoic acid (AP7; $50 \mathrm{nmol} / \mu \mathrm{l}), 6,7$-dinitroquinoxaline2,3-dione (DNQX; $2 \mathrm{nmol} / \mu \mathrm{l}$ ), and NMDA $(0.1 \mathrm{nmol} / \mu \mathrm{l})$ (Research Biochemicals Inc., Natick, MA) all were dissolved in $1 \mathrm{~N} \mathrm{NaOH}, \mathrm{pH}$ adjusted to 7.4 with $0.2 \mathrm{~N} \mathrm{HCl}$, and diluted to stated concentrations with saline.

Treatment of animals and tissue preparation. Forty female SpragueDawley rats $(150-200 \mathrm{gm})$ were used in the in situ hybridization studies, and 24 rats were used in immunohistochemical studies. $\mathrm{KA}(12 \mathrm{mg} / \mathrm{kg})$ was administered intraperitoneally while all other compounds were administered intracerebroventricularly $(10, \mu 1 /$ injection $)$ with a Hamilton syringe. For intracerebroventricular administration animals were anesthetized with halothane and mounted in a stereotaxic frame, and the skull was exposed and holes were drilled with stereotaxic guidance (AP $0.3, \mathrm{~L} 1.4, \mathrm{~V} 4.1$ from bregma) of sufficient size to accommodate the injection cannula. Animals were divided into 10 treatment groups, each group comprising four rats: group I, KA; II, AP7; III, DNQX; IV, AP7 + KA; V, DNQX + KA; VI, vehicle + KA; VII, vehicle; VIII, NMDA; IX, NMDA + AP7; X, untreated. Halothane treatment alone had no significant effect on BDNF mRNA expression in hippocampus (data not shown). When two compounds were used, the second was injected 30 min after the first. For in situ hybridization studies, animals were decapitated and brains removed and frozen 5.5-6 hr after last treatment. Cryostat sections $(14 \mu \mathrm{m})$ of tissue were thawed onto ProbeOn slides (Fischer) and stored at $-20^{\circ} \mathrm{C}$ prior to hybridization.

In situ hybridization. Oligonucleotide probes complementary to BDNF (Leibrock et al., 1989) (bases 250-298), NGF (Whittemore et al., 1988) (bases 374-422), NT3 (bases 827-874) (Hohn et al., 1990), and trkB (Middlemas et al., 1991) (bases 2576-2617 and 723-767) were synthesized (Scandinavian Gene Synthesis) and 3' end labeled with ${ }^{35}$ S-dATP. A sequence complementary to the rat NGF receptor (Radeke et al., 1987) (873-920) mRNA with comparable GC content and a sense oligonucleotide probe corresponding to the NGF probe served as controls. Procedures for in situ hybridization were as described (Dagerlind et al., 1992). Sections were hybridized with specific and control probes for 16 $\mathrm{hr}$ at $42^{\circ} \mathrm{C}$. Slides were either exposed to film for 4-8 weeks or dipped in Kodak NTB2 emulsion, diluted $1: 1$ in distilled water, and exposed for $10-12$ weeks at $-20^{\circ} \mathrm{C}$.

Immunohistochemistry. Rats from groups I, II, V-VII, and X as dctailed above (150 gm female, Sprague-Dawley, ALAB, Sweden) were anesthetized with sodium pentobarbital (Mebumal, $40 \mathrm{mg} / \mathrm{kg}$, i.p.) and perfused via the ascending aorta with $50 \mathrm{ml}$ of $\mathrm{Ca}^{2+}$-free Tyrode's solution followed by $50 \mathrm{ml}$ of formalin-picric acid mixture (4\% paraformaldehyde, $0.4 \%$ picric acid in $0.16 \mathrm{M}$ phosphate buffer; $\mathrm{pH} 6.9$ ). Brains were removed and processed for immunohistochemistry as previously described using antibodies raised against synthetic peptides derived from BDNF and pro-BDNF amino acid sequences (Wetmore et al., $1991,1993)$. Tissues were examined and photographed using epifluorescence microscopy (Nikon-Microphot).

Quantification and evaluation of cell labeling. For evaluation of mRNA signals, measurements were performed on two nonadjacent sections from each brain that had been hybridized, dipped in emulsion, developed, and counterstaincd with cresyl violet. Sections werc analyzed with an image analysis system consisting of a Nikon Microphot microscope, a DAGE-MTI CCD 72 camera linked to an Apple computer containing a Quick Capture frame grabber card, and the IMAGE program (kindly supplied by Dr. Wayne Rasband, NIMH). For quantification each section was digitized by averaging 16 frames and areas to be measured were outlined interactively, as were background areas immediately ad. jacent to the area of interest. Background measures were subtracted from mean optical density measures for areas of interest. Groups I and VI as well as VII and X were not statistically different from each other ( $p>0.05$ Student's $t$ test) and were therefore combined for subsequent analysis. Statistical analysis was performed using a one-way ANOVA with post hoc Bonferroni multiple comparison test where appropriate.

For immunohistochemical evaluation of BDNF immunoreactivity (-IR) after control, KA, and DNQX I KA treatments, brains from six to eight rats from time points $2.5,6,12$, and $18 \mathrm{hr}$ posttreatment were evaluated.

\section{Results}

Specificity controls

Oligonucleotide probes used in these studies labeled bands of appropriate size for BDNF [4.0 and 1.6 kilobases $(\mathrm{kb})]$ on Northern analysis of total RNA from adult rat brain (data not shown). To illustrate that the KA-mediated upregulation in 


\begin{tabular}{|c|c|c|}
\hline Treatment & $\begin{array}{l}\text { Time } \\
\text { (min } \\
\text { post- } \\
\text { injec- } \\
\text { tion) }\end{array}$ & Behavioral observations \\
\hline \multirow[t]{2}{*}{ KA } & $15-20$ & $\begin{array}{l}\text { All rats jumpy, shaking, auditory } \\
\text { sensitive }\end{array}$ \\
\hline & $30-45$ & $\begin{array}{l}\text { All rats seizing, sweating, aggressive } \\
\text { behavior, lacrimation, piloerection }\end{array}$ \\
\hline \multirow[t]{2}{*}{ DNQX } & 30 & $\begin{array}{l}\text { Decreased locomotor activity, flaccid } \\
\text { extremities }\end{array}$ \\
\hline & 60 & $\begin{array}{l}\text { Rats stumbling but able to walk, look } \\
\text { intoxicated }\end{array}$ \\
\hline \multirow[t]{2}{*}{$\mathrm{DNQX}+\mathrm{KA}$} & $30-40$ & $\begin{array}{l}\text { Rats are stumbling, but more alert } \\
\text { than DNQX alone; no seizures, } \\
\text { some head shaking }\end{array}$ \\
\hline & 60 & $\begin{array}{l}\text { Some aggression, some auditory } \\
\text { sensitivity; no seizures; normal } \\
\text { locomotor activity }\end{array}$ \\
\hline \multirow[t]{2}{*}{$\mathrm{AP} 7+\mathrm{KA}$} & 30 & $\begin{array}{l}\text { Laying in cages, flaccid, some rats } \\
\text { moving back legs, piloerection, } \\
\text { lacrimation }\end{array}$ \\
\hline & $60-90$ & $\begin{array}{l}\text { Head shaking, starting to walk, } \\
\text { sniffing, some seizures, less } \\
\text { aggressive than KA alone }\end{array}$ \\
\hline \multirow[t]{2}{*}{ NMDA } & $10-20$ & $\begin{array}{l}\text { Must rats walking and seizing; some } \\
\text { head shaking; not as aggressive as } \\
\text { KA rats }\end{array}$ \\
\hline & 60 & $\begin{array}{l}\text { All rats walking, few seizures, } \\
\text { occasional shaking }\end{array}$ \\
\hline \multirow[t]{2}{*}{ AP7 } & 30 & $\begin{array}{l}\text { Decreased locomotor activity, } \\
\text { decreased muscle tone, piloerection, } \\
\text { lacrimation }\end{array}$ \\
\hline & 90 & $\begin{array}{l}\text { Tense shaking, subdued motion, } \\
\text { lacrimation }\end{array}$ \\
\hline \multirow[t]{3}{*}{$\mathrm{AP7}+\mathrm{NMDA}$} & 30 & $\begin{array}{l}\text { Decreased locomotor activity, } \\
\text { decreased muscle tone, moving head } \\
\text { and back legs }\end{array}$ \\
\hline & 60 & $\begin{array}{l}\text { Decreased locomotor activity, } \\
\text { decreased muscle tone, more alert } \\
\text { but still not walking }\end{array}$ \\
\hline & 90 & $\begin{array}{l}\text { Lethargic movement, some head } \\
\text { shaking }\end{array}$ \\
\hline
\end{tabular}

hippocampal areas is neurotrophin specific and not a generalized kainate-induced nonspecific increase in mRNAs, no labeling was detected with an oligonucleotide probe complementary to the low-affinity NGF receptor, which is not normally expressed by neurons in the rat hippocampus.

The BDNF-specific peptide antibodies used in the present studies have been previously characterized (Wetmore et al., 1991, 1993). All immunostaining was blocked with preabsorption of the antibody with the cognate peptide, as previously described. Upregulation of pro-BDNF-IR was detected in the cytoplasm of pyramidal and granule cells; however, no shift of immunoreactivity was detected in the surrounding neuropil with these antibodies as was noted with the antisera raised against the mature BDNF peptides.

\section{Behavioral observations}

Animals were observed for immediate (5-30 min postadministration) and delayed (30-90 min postadministration) reaction to the pharmacologic agent (Table 1). In each treatment category, most animals exhibited behavioral manifestations consistent with the pharmacological agent used (i.e., seizures after KA and NMDA treatment, lethargy after DNQX and AP7 treatment, no behavioral difference among the vehicle-treated and normal control animals). Such behavioral monitoring scrved to confirm the efficacy of the selected dosage of drug, as well as to eliminate from this study animals appearing less sensitive or unresponsive to a given drug.

\section{Regulation of $B D N F m R N A$}

Following KA exposure, expression of BDNF mRNA was markedly increased in neurons throughout most cortical areas (Fig. $1 B$ ) with highest expression in the granule and pyramidal cell layers of hippocampus (CA1: $F=7.91, p<0.0001$; CA2: $F=$ 10.52, $p<0.0001$; CA3a +b: $F=8.42, p<0.0001$; CA3c: $F$ $=9.99, p<0.0001$; dentate: $F=11.59, p<0.0001)$, and in both superficial and deep pyramidal cell layers of neocortex $(F$ $=21.6, p<0.0001)$ and in the amygdala. More specifically, very dense labeling could be detected over the large pyramidal cells in areas CA2 and CA3 and with smaller cells clearly visible in CA1 and in the dentate granule cell layer. Neocortical areas were all labeled without obvious regional alterations, with heaviest labeling in layers II/III and VI. The kainate-induced upregulation in BDNF mRNA was blocked in most regions by prior treatment of the animals with DNQX (Fig. 1C) (CA1, $p$ $=0.028 ; \mathrm{CA} 2, p=0.065 ; \mathrm{CA} 3 \mathrm{a}+\mathrm{b}, p=0.085 ; \mathrm{CA} 3 \mathrm{c}, p=0.034$; dentate, $p=0.014$; cortex, $p<0.001$ ) (Fig. $1 C$ ), a competitive kainatc reccptor antagonist, but not with AP7 (Fig. 1D) (all regions $p>0.05$ ), a competitive NMDA receptor antagonist. Moreover, no change in basal BDNF expression was observed after DNQX (Fig. $1 E$ ), AP7 (Fig. $1 F)(p>0.05)$, NMDA, or vehicle control treatments (Fig. $1 G$ ) (all regions $p>0.05$ ).

\section{Localization of $\operatorname{trk} B m R N A$ to neurons that also express BDNF $m R N A$}

Expression of mRNA for a truncated transcript of trkB ( $\left.t r k \mathrm{~B}_{\text {trunc }}\right)$ was detected in most, if not all, cells of hippocampus (Fig. $2 B$ ) and other brain regions $(C$. Wetmore, L. Olson, and A. I. Bean, unpublished observations), while full-length transcripts of trkB appeared to be confined to neurons (Fig. $2 A$ ). Based upon examination of consecutive slides hybridized with oligonucleotide probes complementary to BDNF mRNA, it appears that most hippocampal pyramidal cells that express BDNF mRNA and protein also express trkB mRNA. Expression of trkB mRNA was not significantly affected by $\mathrm{KA}$ exposure; however, $\operatorname{trk} \mathrm{B}_{\text {trunc }}$ mRNA was increased $6 \mathrm{hr}$ after KA treatment (not shown), though not as dramatically as detected for BDNF mRNA.

\section{Evaluation of immunohistochernical localization of $B D N F$}

Levels of BDNF-IR were visually rated on a scale of relative intensity [ranging from barely detectable $(+)$ to very strong $(+++++)$, with basal levels of BDNF expression being set at "++" throughout all hippocampal fields except CA2, where basal levels of immunoreactivity were higher and set at " +++ ." Values listed in Table 2 were obtained from evaluation of approximately 30 tissue sections obtained from six to eight rats per time point. 

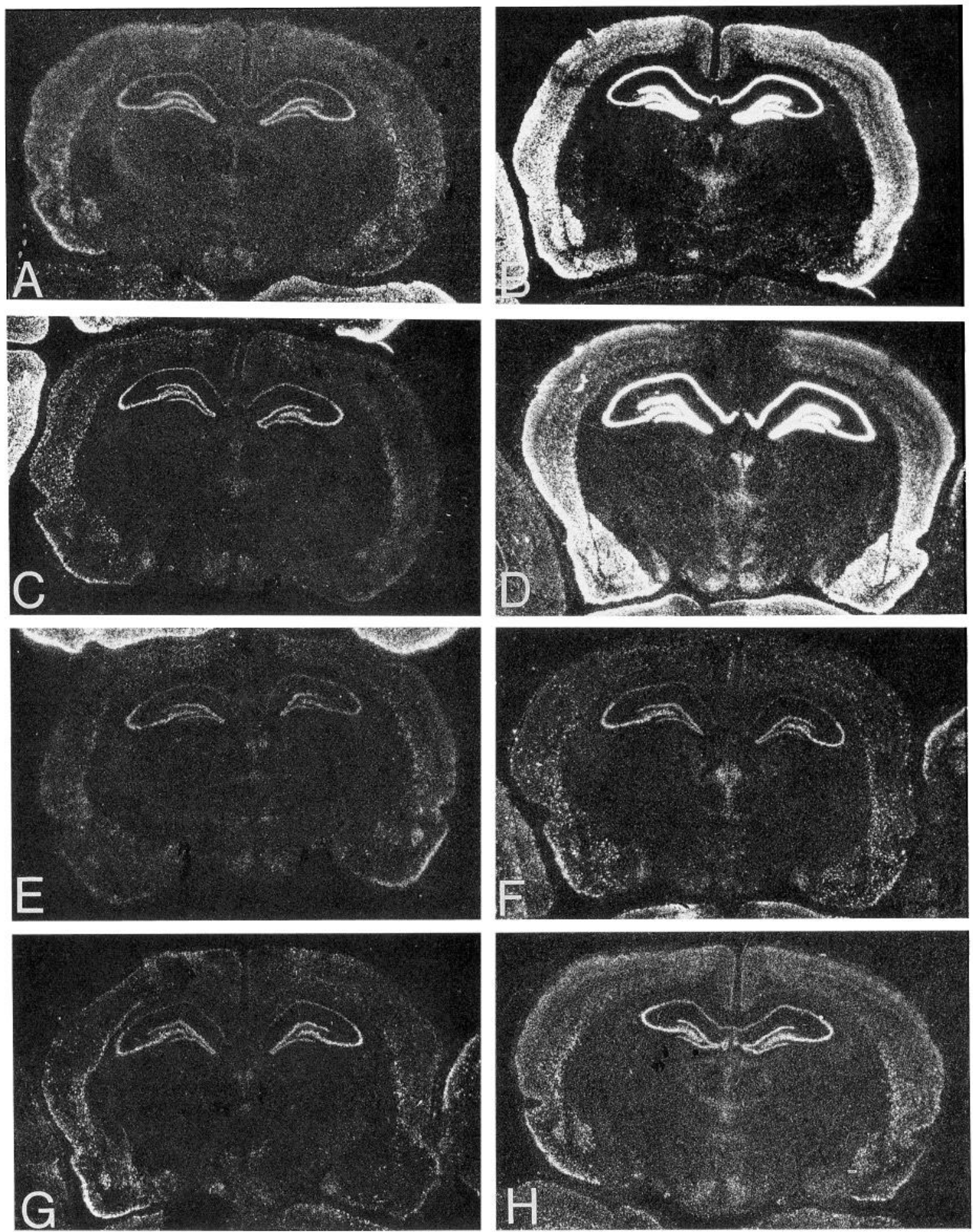

Figure 1. Film autoradiographs of in situ hybridization of adult rat brain $6 \mathrm{hr}$ after treatment with KA and/or glutamate antagonists: $A$, control; $B, \mathrm{KA} ; C, \mathrm{KA}+\mathrm{DNQX} ; D, \mathrm{KA}+\mathrm{AP7} ; E$, DNQX; $F, \mathrm{AP7} ; G, \mathrm{NMDA} ;$ and $H$, vehicle control. Note significant increase in BDNF mRNA after KA exposure $(B)$, which is blocked by prior treatment with DNQX $(C)$ but not with AP7 $(D)$. No change in basal levels of BDNF mRNA were noted after treatment with DNQX $(E)$, AP7 $(F)$, or NMDA $(G)$. Intracranial injection of saline (vehicle control) produced no change in BDNF mRNA $(H)$.

\section{Regulation and distribution of BDNF-IR after KA treatment}

While a significant, kainate-induced increase in BDNF mRNA was detected throughout hippocampal and other cortical areas, this change in mRNA was not paralleled by alterations of equal magnitude and distribution of BDNF protein (Table 2). Specifically, an initial diminution of BDNF-IR in pyramidal cell cytoplasmic compartments was noted with concomitant in- 


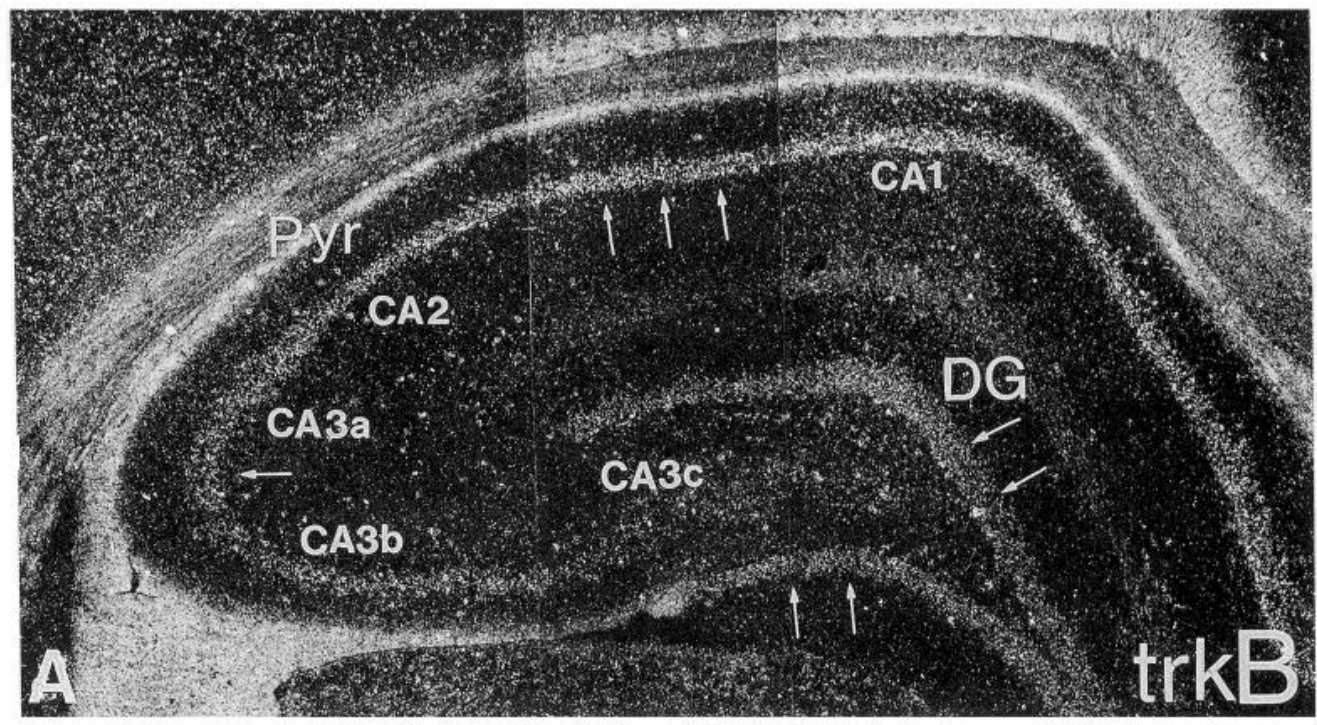

Figure 2. Expression of $\operatorname{trk} \mathrm{B}(A)$ and truncated $t r k \mathrm{~B}(B)$ mRNA transcripts in hippocampus. Note differential cellular expression of $t r k \mathrm{~B}$ predominantly in neurons (arrows) throughout pyramidal cell layer $(P y r)$ and granule cells of the dentate gyrus $(D G)$, and truncated trkB mRNA localized, additionally, to glial cells. Hippocampal subfields $C A 1, C A 2$, and $C A 3 a-c$ are indicated.

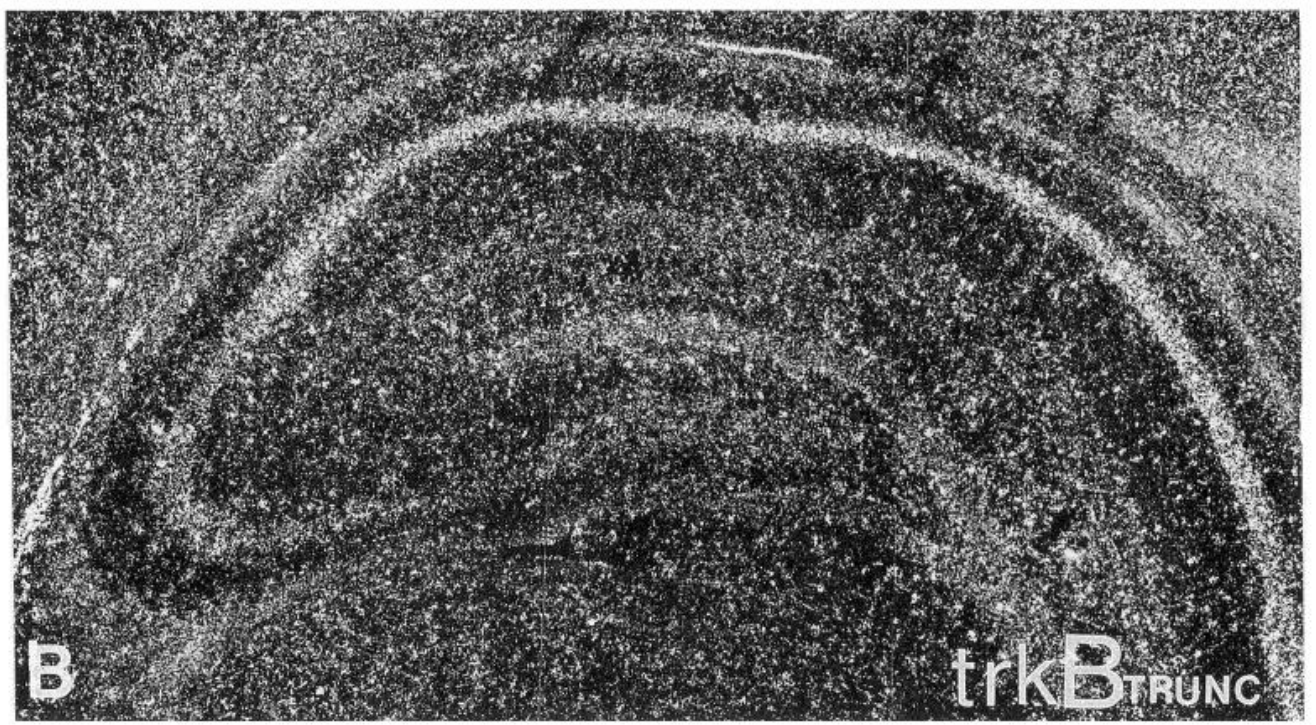

crease in BDNF-IR in the surrounding neuropil of the mossy fiber terminal zones of CA3a-c (Figs. 3, 4). A marked increase in BDNF-IR in the peripheral cytoplasm of neurons in the lateral amygdaloid nucleus was also noted shortly $(2-3 \mathrm{hr})$ after kainate exposure, but without any apparent increase in immunoreactivity of surrounding parenchyma (not shown). At later time points, significant increases in BDNF-IR were detected in somata and proximal dendrites of pyramidal neurons in hippocampus (Fig. $5 E$ ) and in piriform cortex (not shown), while

Table 2. Relative intensities of perikaryal immunostaining of cells in cortical regions containing BDNF-IR after treatment with KA

\begin{tabular}{llllll} 
& Control & $3 \mathrm{hr}$ & $6 \mathrm{hr}$ & $12 \mathrm{hr}$ & $18 \mathrm{hr}$ \\
\hline $\mathrm{DG}$ & ++ & $(+)^{a}$ & $++(+)$ & ++ & +++ \\
$\mathrm{CA} 1$ & ++ & ++ & +++ & $++(+)$ & $(+)$ \\
$\mathrm{CA} 2$ & +++ & $+(+)$ & $+++(+)$ & $+(+)$ & ++++ \\
$\mathrm{CA} 3$ & ++ & + & ++++ & $+(+)$ & $(+)$ \\
Pir & ++ & ++ & +++ & ++++ & $++(+)$
\end{tabular}

"Parentheses indicate a level of " $1 / 2+$ " of intensity of immunoreactivity. more moderate alterations in BDNF-IR were detected in dentate granule cells (Fig. $3 E$ ) and in neocortical areas. The KA-induced upregulation of BDNF mRNA and BDNF-IR was blocked by prior treatment with DNQX (Fig. 6). No glial expression of BDNF-IR was detected in control or in KA-treated animals.

Three hours. A dramatic shift in the localization of BDNFIR was detected 2-3 hr postadministration of KA in the CA3 and the hilar region of dentate gyrus (Figs. 3,4 ) where a bright zone of immunoreactivity was observed in the neuropil surrounding the faintly immunoreactive large pyramidal cells of CA3c (Fig. $4 B$ ) and extending along the pyramidal cell layer in areas $\mathrm{CA} 3 \mathrm{a}+\mathrm{b}$ and CA2 (Figs. $4 B, 5 B$ ). This zone of BDNFIR was coincident with the termination zone of mossy fibers. A similar zone of immunoreactivity in the neuropil was noted in the molecular layer of dentate gyrus (Fig. 3B). Hilar cells (Fig. $4 B)$ and pyramidal cells in hippocampal areas CA2 and CA3 (Fig. $5 B$ ) showed decreased cytoplasmic BDNF-IR, in marked contrast to the strongly immunofluorescent neuropil. BDNF-IR was slightly increased in CA1 neurons, though not as marked as in other hippocampal areas. Slightly decreased immunoreactivity was detected in dentate granule cell (Fig. 3) cytoplasm. Cytoplasmic BDNF-IR in the amygdala was markedly increased 

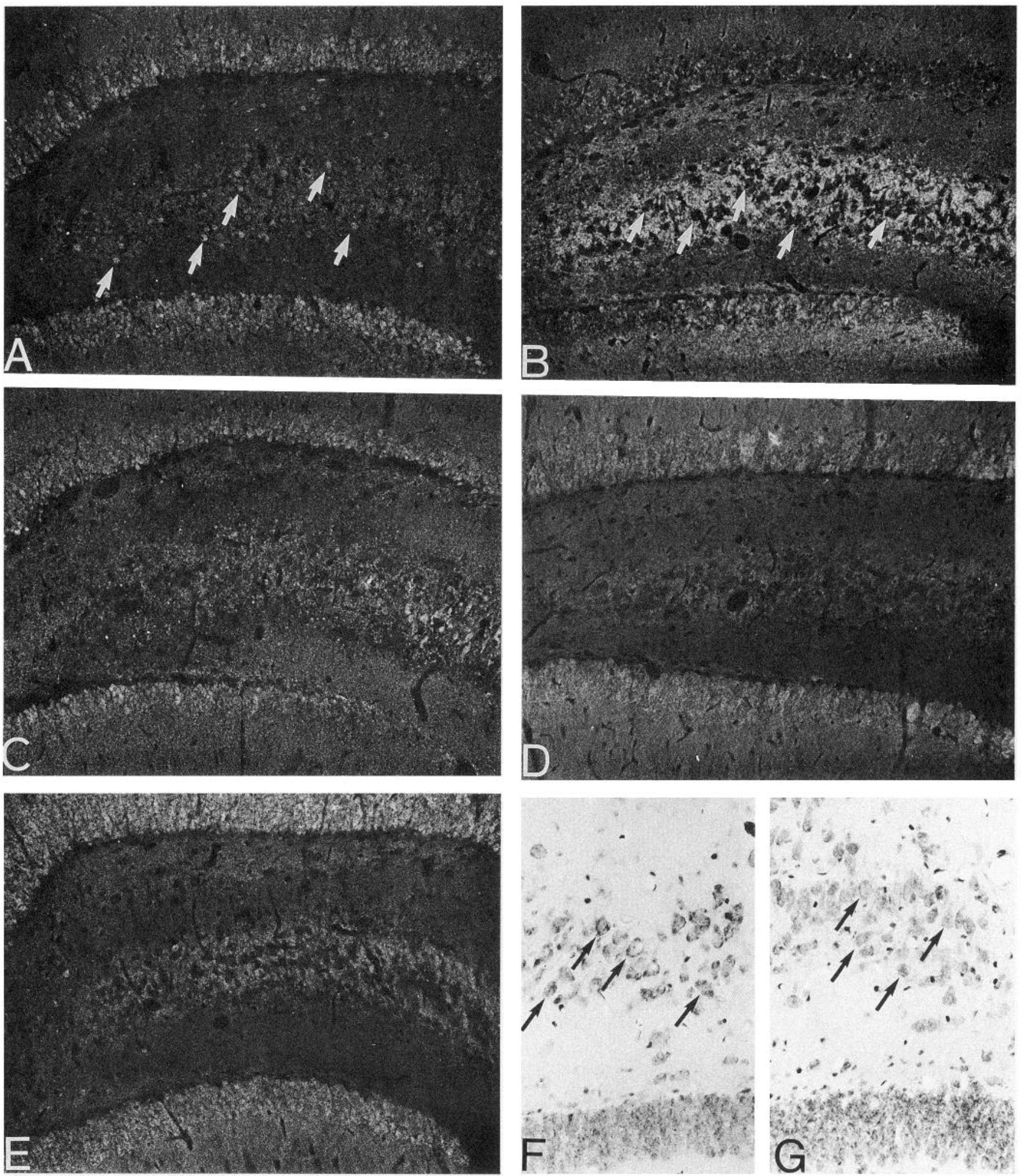

Figure 3. Photomicrographs of BDNF-IR and cresyl violet-stained tissue in dentate gyrus, CA3c, and hilar regions of hippocampus at various time points after KA exposure: $A$, control; $B, 2-3 \mathrm{hr} ; C, 6 \mathrm{hr} ; D, 12 \mathrm{hr} ; E$, $18 \mathrm{hr}$. Representative sections stained with cresyl violet show signs of cellular degeneration and diffusely stained nuclei (arrows) $18 \mathrm{hr}$ after KA exposure $(G)$ as compared with control $(F)$.

in both intensity and in number of cells labeled and was localized to perinuclear cytoplasm (not shown).

Slight changes in BDNF-IR were noted in neurons in the superficial layers of piriform cortex. The somata and proximal dendrites of the neurons in superficial layers (II/III) were more distinctly outlined by an increased peripheral cytoplasmic immunofluorescence, similar in nature but less intense than that observed in the amygdala. 

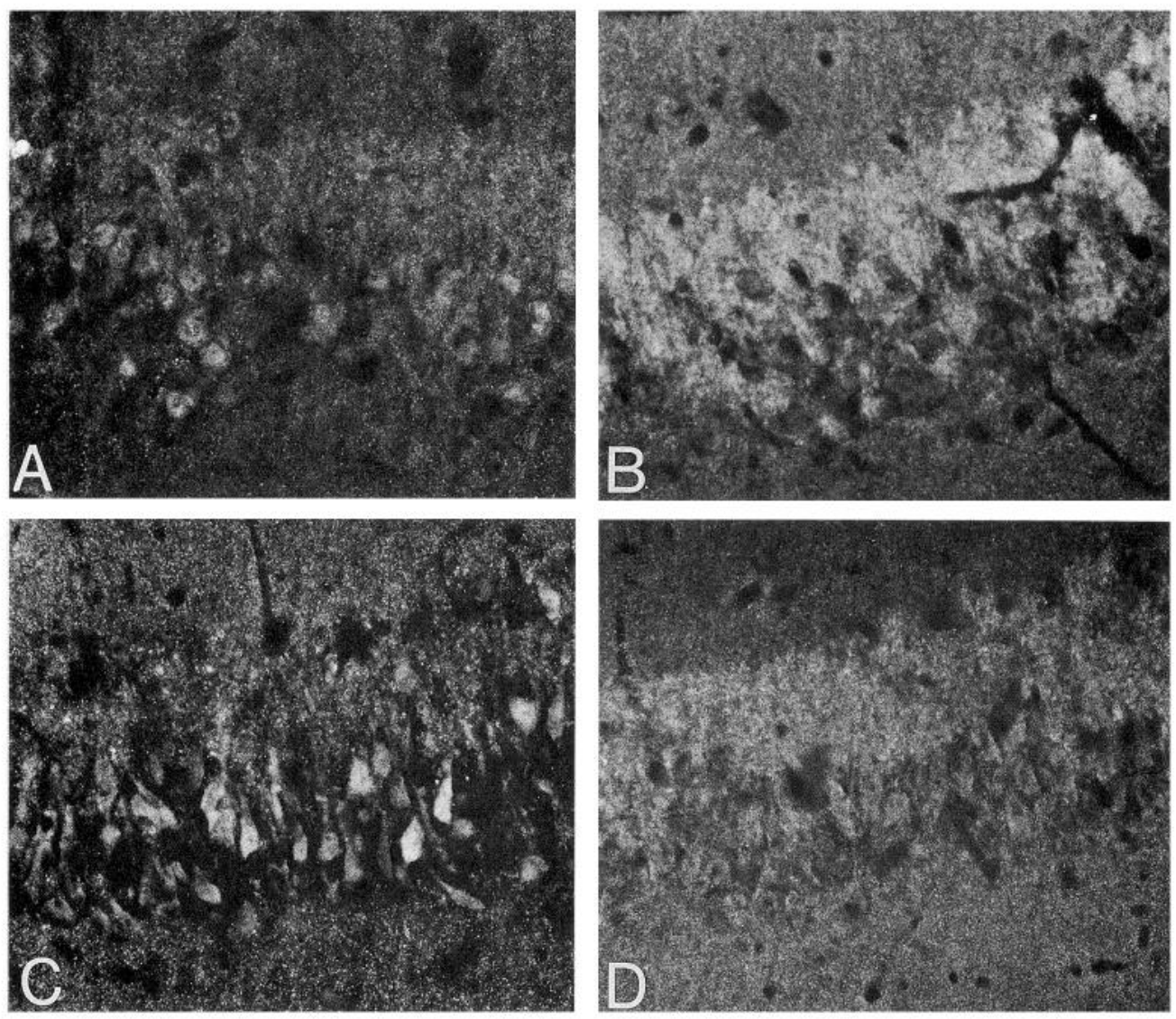

4. Photomicrographs of BDNF-IR and cresyl violet-stained tissue in CA3b region of hippocampus at various time points after KA exposure: $A$, control; $B, 2-3 \mathrm{hr} ; C, 6 \mathrm{hr} ; D, 12 \mathrm{hr}$; $E, 18 \mathrm{hr}$. Note decreased cytoplasmic BDNF-IR in CA3c pyramidal neurons and increased BDNF-IR of parenchyma surrounding these cells at 2-3 $\mathrm{hr}$ post KA treatment $(B)$, followed by a sharp rise in intracellular BDNF-IR at $6 \mathrm{hr}(D)$ after KA exposure. At $18 \mathrm{hr}$ $(E)$, BDNF-IR remains slightly below control levels. Representative sections stained with cresyl violet show degeneration of cell bodies and diffusely stained nuclei with increasing vacuolization in neuropil $18 \mathrm{hr}$ after KA exposure $(G)$ as compared with control $(F)$.
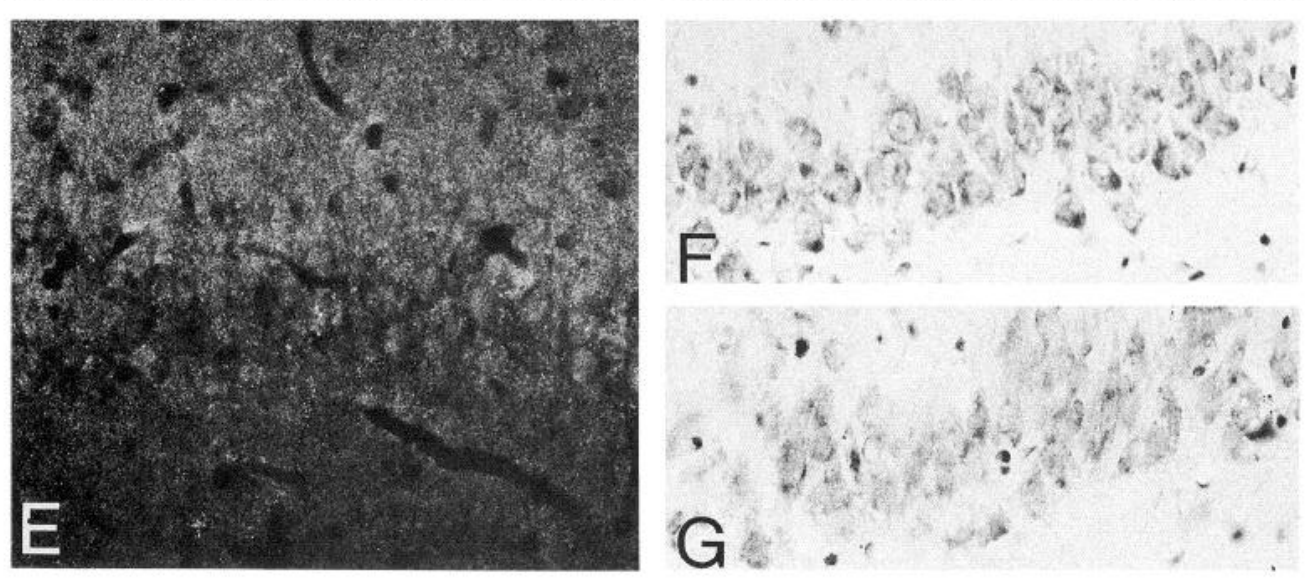

Six to eight hours. BDNF-IR in dentate granule cells returned to control levels, with some very bright, scattered cells (Fig. $3 C$ ). Neuropil surrounding dentate granule cells was darker than seen at $3 \mathrm{hr}$. The highest levels of BDNF-IR in CA1 and CA2 were detected at this time point, with an increase in cytoplasmic BDNF-IR in pyramidal cells in CA3 (Fig. $5 C$ ) and hilar areas (Fig. $4 C$ ), including distinct basal dendrites on neurons in $\mathrm{CA3c}$, which were strongly immunolabeled (Fig. $4 \mathrm{C}$ ). An area of BDNFIR along the inner aspect of CA3, extending into the hilus, coincident with the terminal zone of mossy fibers, was readily apparent and the immunoreactivity appeared weaker and more particulate than at $3 \mathrm{hr}$ (Fig. 5C). Neurons in the superficial layers of piriform cortex showed an increase in BDNF-IR, with a slight darkening of the neuropil in deeper layers.

Twelve hours. BDNF-IR in dentate granule cells appeared somewhat lower than at $6-8 \mathrm{hr}$ and below control levels with faintly outlined cytoplasm visible against the darkened neuropil (Fig. $3 D$ ). Immunoreactivity in hilar cells was extremely weak or absent, other than a faint immunoreaciivity of the neuropil in some brains. CA1 and CA2 immunolabeling was very pronounced, with a further darkening of the cells in hilar (Figs. $3 D$, $4 D$ ) and CA2-3 regions (Fig. $5 D$ ) to below control levels. Some bright, scattered pyramidal cells were detected in areas CA2 and CA3 (Fig. 5D), though there were many more weakly immunoreactive cells as well as dark patches throughout CA3 and extending into the hilar region (Figs. $4 D, 5 D$ ). Neurons in superficial layers of piriform cortex were consistently immunoreactive, and strongly immunolabeled cells were easily detected scattered throughout deeper layers of the darkened neuropil.

Eighteen hours. BDNF-IR in dentate granule cells was equal 
The Journal of Neuroscience, March 1994, 14(3) 1695
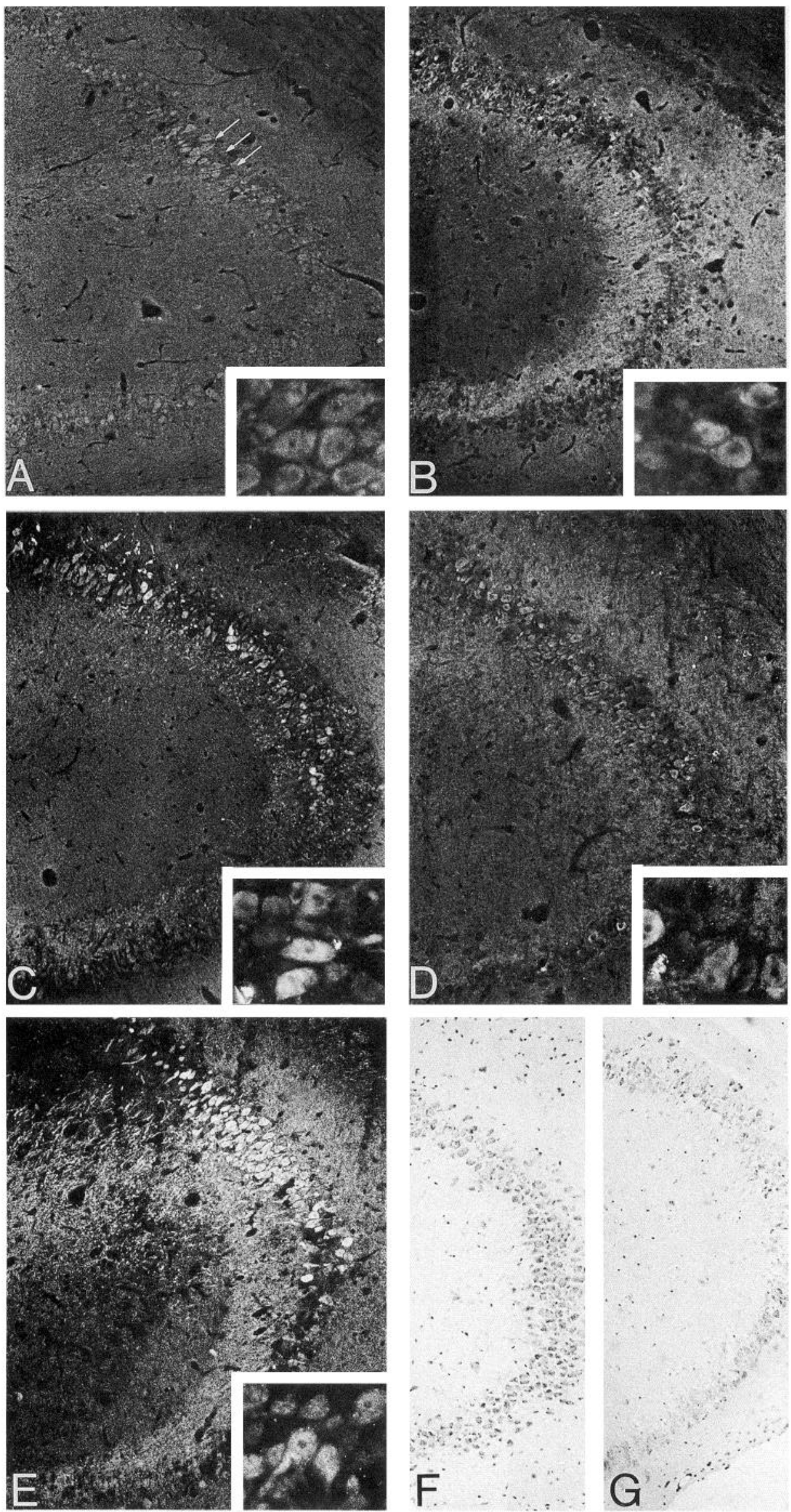
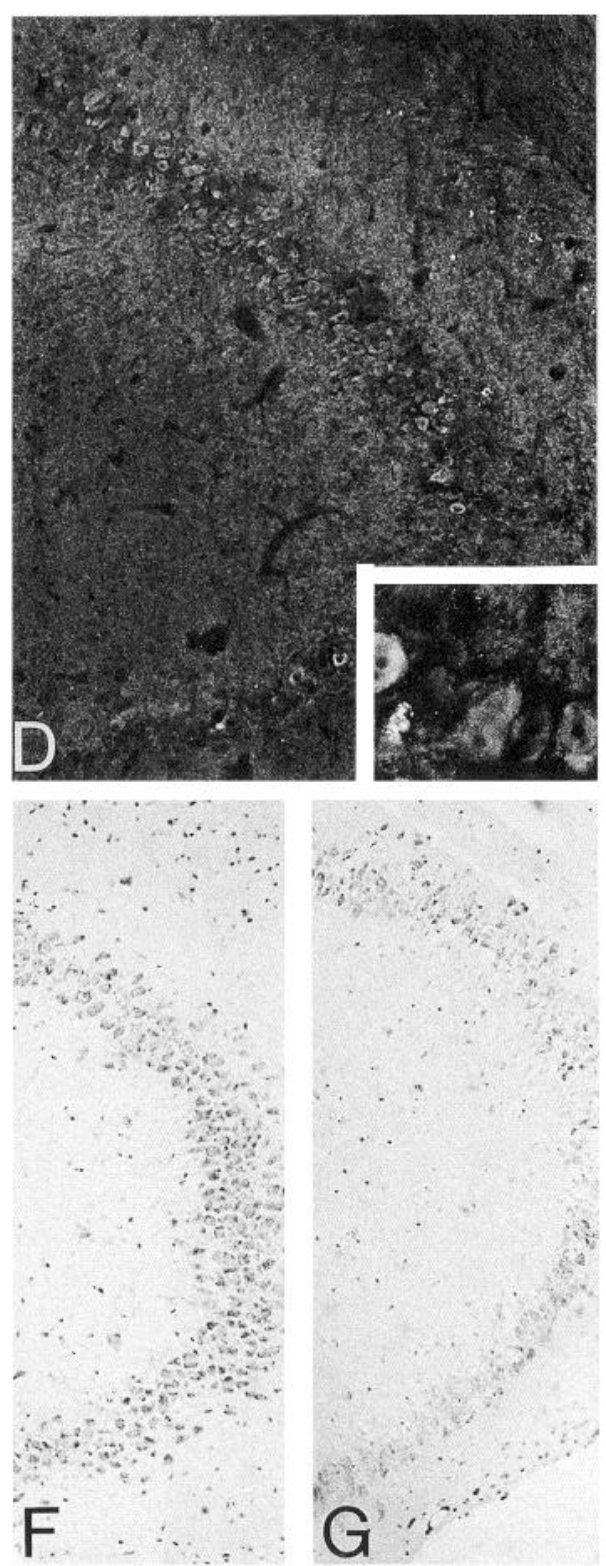

Figure 5. Photomicrographs of BDNF-IR and cresyl violet-stained tissue in CA2-CA3a regions of hippocampus at various time points after KA exposure: $A$, control; $B, 2-3 \mathrm{hr} ; C, 6 \mathrm{hr}$ $D, 12 \mathrm{hr} ; E, 18 \mathrm{hr}$. Insets show high magnification of cells in CA2. Note 2$3 \mathrm{hr}$ after KA exposure BDNF-IR is only faintly detected in pyramidal cell cytoplasm while a marked increase in BDNF-IR was detected in mossy fiber terminal zone $(B)$. At $6 \mathrm{hr}(\mathrm{C})$ BDNFIR in CA2 pyramidal neurons (arrows) is above control levels $(A)$, falls back to approximately control levels at $12 \mathrm{hr}$ $(D)$, and again is increased at $18 \mathrm{hr}$, most markedly in CA2 $(E)$. Representative sections stained with cresyl violet show marked degeneration of cell bodies and distortion of the architecture of pyramidal cell layer; shrunken, pyknotic somata; and increased vacuolization of surrounding neuropil $18 \mathrm{hr}$ after KA exposure $(G)$ as compared with control $(F)$. 

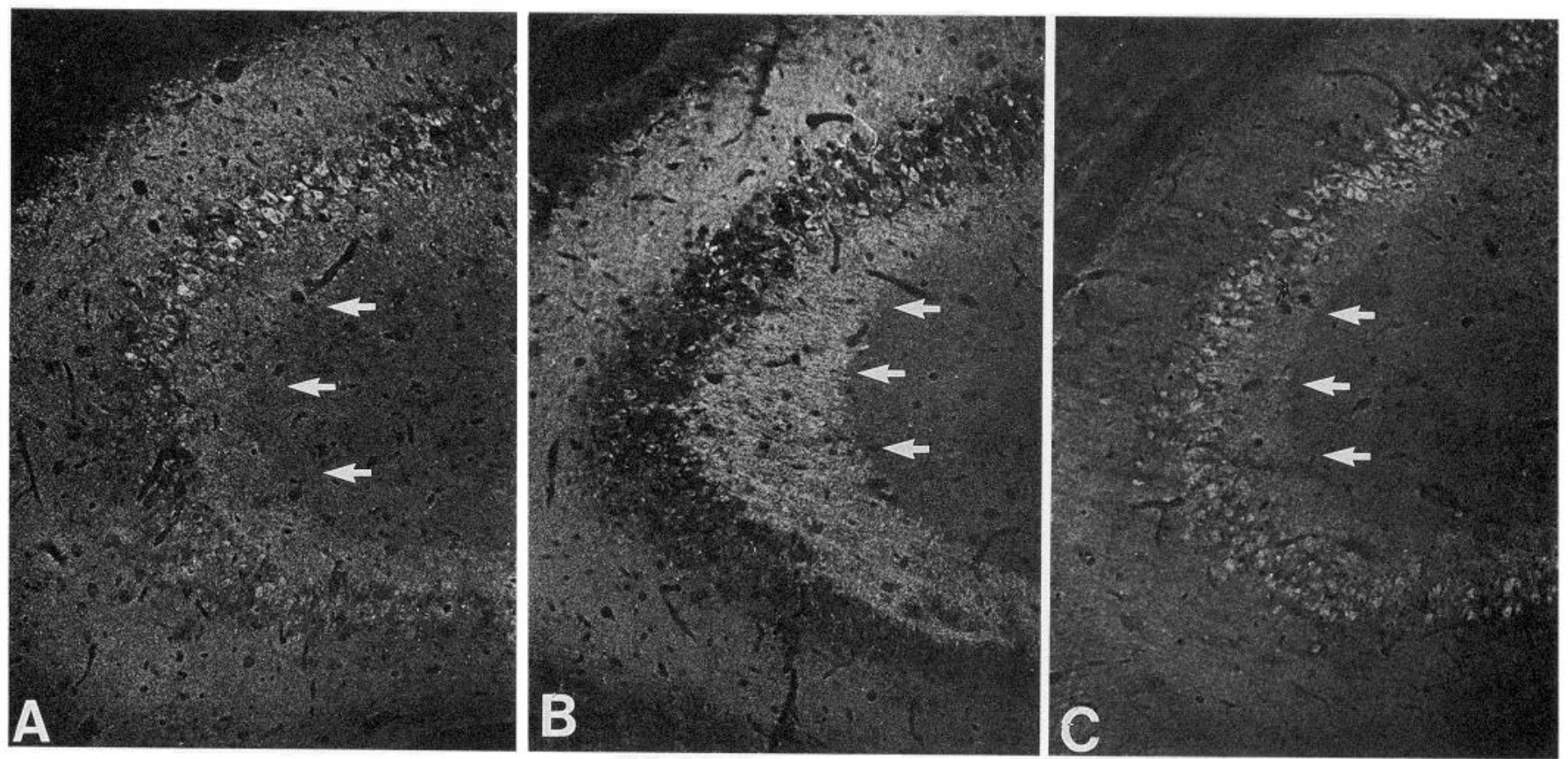

Figure 6. Photomicrograph of BDNF-IR in CA2-CA3a regions of hippocampus (similar view as shown in Fig. 4) at 2-3 hr after saline treated control rats $(A), 2-3 \mathrm{hr}$ after KA treatment $(B)$, and 2-3 hr after DNQX and KA treatment $(C)$ (DNQX given 30 min prior to KA treatment). Note increased BDNF-IR in mossy fiber terminal zone in CA3 $(B)$ at $2-3 \mathrm{hr}$ after KA exposure, which was essentially blocked by prior treatment with the non-NMDA antagonist DNQX $(C)$.

to, or slightly above, control levels (Fig. $3 E$ ). The outline of dark hilar cells could be detected in the slightly increased background immunostaining of the neuropil (Figs. 3, 4E). Many neurons in CA3 and CA1 did not contain any BDNF-IR (Fig. $5 E$ ) and were pale and diffuse with pyknotic or absent nuclei on cresyl violet-stained sections (Figs. $4 F, G ; 5 F, G$ ). The remaining pyramidal cells in CA2 and scattered cells in CA1 and CA3 were brightly immunoreactive with distinct nuclei (Fig. $5 E$ ). Pyramidal cell somata and dendrites in CA2 were markedly immunoreactive and did not demonstrate detectable cytopathology (Fig. $5 F, G$ ).

\section{$K A$-induced alterations in BDNF-IR were substantially blocked by DNQX}

Consistent with the regulation of BDNF mRNA via non-NMDA glutamate receptors, kainate-induced increases in cytoplasmic and local release into the parenchyma of BDNF-IR were substantially blocked by prior treatment with DNQX (Fig. 6). No increase in BDNF-IR was detected in cortical neurons of layers II and IV/V, and the striking shift of BDNF-IR from somatic compartments to the surrounding neuropil was not seen after treatment with DNQX prior to KA administration. However, there did appear to be a slight increase in BDNF-IR in the peripheral cytoplasm of pyramidal neurons of $\mathrm{CA} 2$ and CA3 hippocampal areas in some animals after DNQX + KA treatment (Fig. $6 \mathrm{C}$ ), indicating that there appeared to be some KAinduced alteration of neurotrophin protein levels despite the prior treatment with DNQX, which was not detected at the level of mRNA.

\section{Discussion}

The present data suggest that glutamate may regulate cortical BDNF expression via kainate receptors, but not NMDA receptors. Increases in BDNF mRNA expression in response to KA were antagonized by DNQX, while AP7 had no significant effect on the elevated BDNF mRNA levels. Basal BDNF mRNA expression was not altered by interruption of the tonic glutamate activity by treatment with AP7 or DNQX at doses that elicited behavioral manifestations (Table 1), yet were not noted to induce significant alterations in expression of BDNF mRNA. Alterations in BDNF protein were observed in response to KA in cortical areas with an altered temporal and spatial distribution than that noted for BDNF mRNA, including a marked shift from intracellular somatic compartments to the surrounding parenchyma and/or neuropil at early time points.

Previous studies have shown that exposure to KA induces a dramatic increase in NGF and BDNF mRNA in the hippocampus (Ballarín et al., 1991; Gall et al., 1991; Dugich-Djordjevic et al., 1992; for review, see Gall, 1992). The KA-induced upregulation of neurotrophin mRNA in vitro was blocked by nonNMDA antagonists (Zafra et al., 1990), although the types of cells in which this modulation took place was not determined. In vitro, the KA-mediated upregulation of $\mathrm{BDNF}$ and $\mathrm{NGF}$ mRNA is blocked by the non-NMDA receptor antagonist 6-cyano-7-dinitroquinoxaline-2,3-dione (Zafra et al., 1990), while under basal conditions both NGF and BDNF mRNA appear to be regulated via NMDA receptors and not significantly affected by the non-NMDA receptor antagonist NBQX (Zafra et al., 1991). In vivo, both NMDA and non-NMDA receptor antagonists have been reported to modulate the expression of BDNF and NGF, as determined by Northern blot and quantitative polymerase chain reaction analyses, respectively (Zafra et al., 1991). The results of the present study concur with the Northern blot analysis of neurotrophin mRNA levels reported by Zafra and colleagues (1991) with respect to the non-NMDA receptor-mediated upregulation of BDNF after KA exposure. In addition, the present study illustrates the subpopulations of cells in which this increased expression of BDNF mRNA occurs, 
as well as provides novel data regarding the regulation and potential sites of local release of BDNF protein.

Alterations in basal levels of BDNF expression at the cellular level were not detected after exposure to NMDA or the NMDA antagonist AP7. Moreover, a recent study has reported that the BDNF gene contains multiple promoters, some of which contain sequences that may be differentially responsive to the activation of non-NMDA receptors and can control regionally specific expression of BDNF mRNA in the brain (Timmusk et al., 1993). Thus, inconsistencies among studies may be attributed to such differentially regulated neurotrophin transcripts and/or methodological differences (e.g., analysis of extracts of tissue homogenates as compared to the histological evaluation of alterations in expression at the cellular level). As the cellular expression of neurotrophins is heterogeneous with respect to the level and distribution of cells, it is not possible to note modest alterations in neurotrophin expression of individual cells when analyzing tissue homogenates.

KA-induced alterations in BDNF-IR were primarily detected in neurons in the hippocampus, piriform cortex, and amygdala, with a significant shift of the BDNF-IR from cellular compartments into the surrounding parenchyma and neuropil in the mossy fiber terminal zone $2-3 \mathrm{hr}$ after treatment, which was substantially blocked by prior administration of DNQX. The increase in BDNF-IR after KA in the mossy fiber termination zone was observed to have a similar time course as that which has been reported for early histopathological changes of pyramidal neurons, including shrinkage of neuronal perikarya and swelling of dendrites and axon terminals (Sperk et al., 1983). Such changes were noted $3 \mathrm{hr}$ after KA lesion and were reversible (Sperk et al., 1983). A very pronounced increase in BDNF-IR was seen in the termination zone of the mossy fibers, which are known to contain a high density of kainate binding sites (Represa et al., 1987). The mossy fibers originate from dentate granule cells, which show a rapid and marked increase in BDNF mRNA 30 min post-KA, and project extensively to CA3 pyramidal cells of hippocampus (Blackstad et al., 1970; Lynch et al., 1973; Gaarskjaer, 1978). While pyramidal cells are destroyed by moderate doses of intracerebroventricularly administered KA, dentate granule cells are not (Nadler et al., 1981). However, electron-dense degeneration of mossy fiber boutons were detected though there was not apparent damage to the cell bodies at 4 $\mathrm{hr}$ after intraventricular injection of KA (Nadler et al., 1981). Interestingly, intraperitoneal administration of KA (as used in the present study) also results in degeneration of CA3 pyramidal cells but without apparent ultrastructural damage to mossy fibers as seen after intraventricular administration of the neurotoxin (Olney et al., 1979). Our data support the finding that granule cells are intact and able to maintain cellular function at $6 \mathrm{hr}$ postintraperitoneal administration of $\mathrm{KA}$, and, in fact, increase the expression of BDNF mRNA and protein, as well

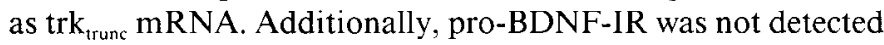
in the neuropil or in mossy fiber terminal zones as noted for BDNF-IR. Thus, alterations in BDNF-IR in the mossy fiber terminal zone reported in the present study cannot be explained solely by ultrastructural changes and degeneration of the mossy fibers, which may allow cellular contents to diffuse out of compromised membranes.

After kainate-induced damage to the hippocampal system, an enhancement of Timm's staining has been observed in this region and was correlated to extensive mossy fiber sprouting (Represa et al., 1987) and a "restructuring" of the mossy fiber projections (Nadler et al., 1981). Thus, an increased local availability of BDNF may support some of the cellular changes (e.g., sprouting, establishment of new synapses) observed after neuronal damage in experimental as well as in disease states (see Mattson, 1989; Sutula et al., 1989; Cavazos et al., 1991; Patterson et al., 1992; see Ben-Ari and Represa, 1990). Interestingly, expression of BDNF remains elevated in granule and pyramidal neurons of pentylenetetrazol-kindled rats for as long as $10 \mathrm{~d}$ after the last injection (Humpel et al., 1993), indicating that the upregulation of BDNF expression may not simply be a response to acute stress.

The general trend in hippocampal areas $\mathrm{CA} 2$ and $\mathrm{CA} 3$ with respect to BDNF-IR was one of a dramatic and marked shift or "release" in to the surrounding parenchyma, accompanied by a decrease in intracellular BDNF-IR (seen throughout all hippocampal areas). Subsequently, cellular BDNF-IR increased above control levels and, in some cases, was accompanied by cell death throughout hippocampal areas (CA3 and hilus) with marked sparing of CA2. Six hours after KA exposure, the levels of BDNF-IR were dramatically increased in pyramidal cells in CA2 and scattered throughout $C A 1$ and $C A 3$, with a particularly strong immunolabeling in CA3 pyramidal cells, known to be 3 orders of magnitude more sensitive to KA than neurons in CA1 (Robertson and Deadwyler, 1981). The different spatial and temporal modulation of BDNF-IR is consistent with regional alterations in BDNF mRNA and with the known distribution of kainate binding sites (Monaghan et al., 1983).

The dramatic increase of BDNF-IR in the neuropil and surrounding tissue in CA3 areas is especially interesting with respect to implications that this shift of the protein localization has for the release and action of BDNF in the unperturbed nervous system. While decreased levels of NGF protein have been reported in the hippocampus and septum after a partial reduction in tonic glutamate activity by NMDA receptor blockade (Zafra et al., 1991), it has not been demonstrated whether this blockade directly interferes with protein release or, moreover, whether neurotrophins are released from neurons via regulated and/or constitutive pathways. It has been demonstrated that neuropeptides are transported in regulated secretory pathways and are difficult to detect in neuronal perikarya without experimental manipulation, yet are readily detected in areas of comparatively higher concentration such as axon terminals (Elde et al., 1978). In contrast, it appears that BDNF-IR is more readily detected in somatic compartments, and has not yet been detected in axons (Wetmore et al., 1991). Our data indicate that after excitatory amino acid stimulation, BDNF-IR can be released from somatic and/or dendritic sites and appears not to be confined to release from sites at axon terminals, which is suggestive of constitutive release. One may also speculate that such a shift in BDNF-IR from cells to the surrounding parenchyma may simply be further evidence of cellular damage and is a result of compromised neuronal membranes, allowing the cytoplasmic contents to spill into the surrounding tissue. Howcver, the apparent shift in localization of BDNF-IR is detcetcd 2-3 hr after KA exposure, at a time when expression of BDNF mRNA has yet to peak (Dugich-Djordjevic et al., 1992; C. Wetmore and A. J. Bean, unpublished observations), suggest that the neurons are, in fact, maintaining metabolic function and activity at a rate higher than basal levels, which could not be occurring if the cell membranes were sufficiently compromised to allow the diffusion of a protein the size of BDNF out of the neuron. BDNF mRNA levels remain elevated for several days 
in dentate and hilar areas of hippocampus (Dugich-Djordjevic et al., 1992). Additionally, while an increase in pro-BDNF-IR was also detected within the perikarya of pyramidal and granule cells, pro-BDNF-IR was not localized to any extracellular or neuropil compartments, suggesting that pro-BDNF is not released from the neuron.

It is interesting to note that, in addition to established sites of BDNF transcription and translation, there also exist sites of possible BDNF action in hippocampal and other cortical areas, as demonstrated by the localization of $\mathrm{mRNA}$ for various transcripts of $t r k \mathrm{~B}$ (Fig. 2), the putative BDNF receptor (Soppet et al., 1991; Squinto et al., 1991). Several transcripts of trkB have been reported; however, only the full-length transcript encodes an intracellular tyrosine kinase domain that appears necessary for transducing intracellular biological response (Klein et al., 1990; Middlemas et al., 1991). The present study indicates that the full-length $t r k \mathrm{~B}$ transcript is confined to neuronal sites of expression, while truncated (i.e., not containing the tyrosine kinase domain) forms of $t r k \mathrm{~B}$ mRNA are also expressed by glial cells (Fig. 2B). Preliminary evidence suggests that cellular levels of expression of truncated forms of trkB are increased after systemic KA exposure, while the expression of full-length trkB transcript is not (Wetmore and Bean, unpublished observations). A similar upregulation of trkB $\mathrm{mRNA}$ has been reported in scar tissue in the spinal cord after lesion of the dorsal funiculus (Frisén et al., 1992). These data provide an interesting basis for speculation on the possibility of different physiological roles for $\operatorname{trk} \mathrm{B}$ and $t r k \mathrm{~B}_{\text {trunc }}$ in damaged neuronal tissues. Specifically, it may be that the truncated forms of $\operatorname{trk} \mathrm{B}$, which lack the intracellular, signal-transducing, tyrosine kinase domain, are inserted into the membrane and act as extracellular binding proteins, which serve to "anchor" ambient BDNF to the cell membrane and thereby establish a concentrated source or gradient of BDNF supportive of local fiber outgrowth, analogous to that which has been suggested for the low-affinity NGF receptor in Schwann cells (Taniuchi et al., 1986). The release of BDNF into surrounding parenchyma may be relevant to the maintenance of synaptic plasticity and, in particular, may play a critical rolc in supporting the sprouting of collateral mossy fibers as has been reported to occur after KA lesion (Cotman et al., 1984; Cotman, 1985; Represa et al., 1987).

In conclusion, we provide evidence from in vivo studies at the cellular level for the regulation of BDNF $m$ RNA and protein via kainate but not NMDA receptors. Significant alterations in the cellular compartmentalization of BDNF-IR were detected in hippocampal and, to a lesser degree, other cortical areas after $\mathrm{KA}$ exposure. The modulation of neurotrophin expression and protein levels in restricted subpopulations of neurons by neuronal activity suggests that neurotrophins may be involved in CNS function in a capacity beyond trophic maintenance of connections, that is, in cell homeostasis and in a possible type of "protection" when cells are subjected to supraphysiologic stress such as seizures or in neurodegenerative disease. The present study localized mRNA for two forms of the putative BDNF receptor, trkB, to an overlapping population of neurons that also appear to have the capability to transcribe and translate an endogenous ligand for this receptor, BDNF. These data suggest the possibility for local mechanisms of BDNF release from the dendrites and/or somata and provide evidence of receptor components necessary for biologically relevant response to this neurotrophin, which are of particular importance in the trophic support of sprouting and synaptic changes described in kindling and temporal lobe epilepsy. The capability for modulation of trophic factor levels by endogenous transmitter systems may provide a physiologic mechanism for maintaining plasticity in the CNS.

\section{References}

Alderson RF, Alterman AL, Barde YA, Lindsay RM (1990) Brainderived neurotrophic factor increases survival and differentiated functions of rat septal cholinergic neurons in culture. Neuron 5:297-306.

Ballarin M, Ernfors P, Lindefors N, Persson H (1991) Hippocampal damage and kainic acid injection induce a rapid increase in mRNA for BDNF and NGF in the rat brain. Exp Neurol 1 14:35-43.

Barde YA (1989) Trophic factors and neuronal survival. Neuron $2: 1525-1534$.

Barde YA (1990) The nerve growth factor family. Prog Growth Factor Res 2:237-248.

Ben-Ari, Represa A (1990) Brief seizure episodes induce long-term potentiation and mossy fibre sprouting in the hippocampus. Trends Neurosci 13:312-318.

Berger M, Ben-Ari Y (1983) Autoradiographic visualization of $\left[{ }^{3} \mathrm{H}\right]$ kainic acid receptor subtypes in the rat hippocampus. Neurosci Lett $39: 237-242$.

Blackstad TW, Brink K, Hem J, June B (1970) Distribution of hippocampal mossy fibers in the rat. An experimental study with silver impregnation methods. J Comp Neurol 138:433-450.

Boulter J, Hollmann M, O'Shea GA, Hartley M, Deneris E, Maron C, Heinemann S (1990) Molecular cloning and functional expression of glutamate receptor subunit genes. Science 249:1033-1037.

Brooks WJ, Petit TL, LeBoutillier JC, Lo R (1991) Rapid alteration of synaptic number and postsynaptic thickening length by NMDA: an electron microscopic study in the occipital cortex of postnatal rats. Synapse 8:41-48.

Cavazos JE, Golarai G, Sutula TP (1991) Mossy fiber synaptic reorganization induced by kindling: time course of development, progression and permanence. J Neurosci 11:2795-2803.

Choi DW (1990) Methods for antagonizing glutamate neurotoxicity. Cerebrov Brain Metab Rev 2:105-147.

Cole AJ, Saffen DW, Baraban JM, Worley PF (1989) Rapid increase of an immediate early gene messenger RNA in hippocampal neurons by synaptic NMDA receptor activation. Nature 340:474-476.

Cornell-Bell AH, Thomas PG, Smith SJ (1990) The excitatory neurotransmitter glutamate causes filopodia formation in cultured hippocampal astrocytes. Glia 3:322-334.

Cotman CW (1985) Synaptic plasticity. New York: Guilford

Cotman CW, Nieto-Sampedro M (1984) Cell biology of synaptic plasticity. Science 225:1287-1293.

Cotman CW, Monaghan DT, Ottersen OP, Storm-Mathisen J (1987) Anatomical organization of excitatory amino acid receptors and their pathways. Trends Ncurosci 10:273-280.

Dagerlind Å, Friberg K, Bean AJ, Hökfelt T (1992) Sensitive mRNA detection using unfixed tissue: combined radioactive and non-radioactive in situ hybridization histochemistry. Histochemistry 98:39-49.

Dugich-Djordjevic MM, Tocco G, Lapchak PA, Pasinetti GM, Najm I, Baudry M, Hefti F (1992) Regionally specific and rapid increases in brain-derived neurotrophic factor messenger RNA in the adult rat brain following seizures induced by systemic administration of kainic acid. Neuroscience 47:303-315.

Elde R, Hökfelt T, Johansson O, Ljungdahl Å, Nilsson G, Jeffcoate SL (1978) Immunohistochemical localization of peptides in the nervous system. In: Centrally acting peptides (Hughes J, ed), pp 17-35. London: Macmillan.

Ernfors P, Ibáñez CF, Ebendal T, Olson L, Persson H (1990a) Molecular cloning and ncurotrophic activitics of a protein with structural similarities to nerve growth factor: developmental and topographical expression in the brain. Proc Natl Acad Sci USA 87:5454-5458.

Ernfors P, Wetmore C, Olson L, Persson H (1990b) Identification of cells in rat brain and peripheral tissues expressing mRNA for members of the nerve growth factor family. Neuron 5:511-526.

Frisén J, Verge VMK, Cullheim S, Persson H, Fried K, Middlemas DS, Hunter T, Hökfelt T, Reisling M (1992) Increased levels of trkB $m R N A$ and trkB protein-like immunoreactivity in the injured rat and cat spinal cord. Proc Natl Acad Sci USA 89:11282-11286.

Gaarskjaer FB (1978a) Organization of the mossy fiber system of the 
rat studied in extended hippocampi. I. Terminal area related to number of granule and pyramidal cells. J Comp Neurol 178:49-72.

Gaarskjaer FB (1978b) Organization of the mossy fiber system of the rat studied in extended hippocampi. II. Experimental analysis of fiber distribution with silver impregnation methods. J Comp Neurol 178: $73-88$.

Gall CM (1992) Regulation of brain neurotrophin expression by physiological activity. Trends Pharmacol Sci 13:401-403.

Gall CM, Isackson PJ (1989) Limbic seizures increase neuronal production of messenger RNA for nerve growth factor. Science $245: 758-$ 761.

Gall C, Sumikawa K, Lynch G (1990) Levels of mRNA for a putative kainate receptor are affected by seizures. Proc Natl Acad Sci USA 87: 7643-7647.

Gall C, Murray K, Isackson PJ (1991) Kainic acid-induced seizures stimulate increased expression of nerve growth factor mRNA in rat hippocampus. Mol Brain Res 9:113-123.

Geddes JW, Monaghan DT, Cotman CW (1985) Plasticity of hippocampal circuitry in Alzheimer's disease. Science 230:1179-1181.

Geinisman Y, Morrell F, deToledo ML (1992) Increase in the number of axospinous synapses with segmentcd postsynaptic densities following hippocampal kindling. Brain Res 569:341-347.

Greenamyre JT, Penney JB, Young AB, D'Amato CJ, Hicks SP, Shoulson I (1985) Alterations in L-glutamate binding in Alzheimer's and Huntington's diseases. Science 227:1496-1499.

Hallböök F, Ayer-Lelièvre C, Ebendal T, Persson H (1990) Expression of nerve growth factor receptor mRNA during early development of the chicken embryo: emphasis on cranial ganglia. Development 108: 693-704

Hefti $F$ (1986) Nerve growth factor promotes survival of septal cholinergic neurons after fimbrial transection. J Neurosci 6:2155-2162.

Hofer M, Pagliusi SR, Hohn A, Leibrock J, Barde YA (1990) Regional distribution of brain-derived neurotrophic factor mRNA in the adult mouse brain. EMBO J 9:2459-2464.

Hohn A, Lcibrock J, Bailcy K, Barde Y-A (1990) Identification and characterization of a novel member of the nerve growth factor/brainderived neurotrophic factor family. Nature 344:339-341.

Humpel C, Wetmore C, Olson L (1993) Regulation of brain-derived neurotrophic factor messenger RNA and protein at the cellular level in pentylenetetrazol-induced epileptic seizures. Neuroscience 53:909918.

Hyman C, Hofer M, Barde YA, Juhasz M, Yancopoulos GD, Squinto SP, Lindsay RM (1991) BDNF is a neurotrophic factor for dopaminergic neurons of the substantia nigra. Nature 350:230-232.

Isackson PJ, Huntsman MM, Murray KD, Gall CM (1991) BDNF mRNA expression is increased in adult rat forebrain after limbic seizures: temporal patterns of induction distinct from NGF. Neuron 6:937-948

Kaisho Y, Yoshimura K, Nakahama K (1990) Cloning and expression of a cDNA encoding a novel human neurotrophic factor. FEBS Lett 266:187-191

Kandel ER, Schwartz JH, Jessell TM (1991) Principles of neural science, 3d ed. New York: Elsevier.

Klein R, Parada LF, Coulier F, Barbacid M (1989) trkB, a novel tyrosine protein kinase receptor expressed during mouse neural development. EMBO J 8:3701-3709.

Klein R, Martin-Zanca D, Barbacid M, Parada LF (1990) Expression of the tyrosine kinase receptor gene trkB is confined to the murine embryonic and adult nervous system. Development 109:845-850.

Knïsel B, Winslow JW, Rosenthal A, Rurton LE, Seid DP, Nikolics K, Hefti F (1991) Promotion of central cholinergic and dopaminergic neuron differentiation by brain-derived neurotrophic factor but not neurotrophin 3. Proc Natl Acad Sci USA 88:961-965.

Koliatsos VE, Nauta HJ, Clatterbuck RE, Holtzman DM, Mobley WC, Price DL (1990) Mouse nerve growth factor prevents degeneration of axotomized basal forebrain cholinergic neurons in the monkey. $\mathrm{J}$ Neurosci 10:3801-3813.

Leibrock J, Lottspeich F, Hohn A, Hofer M, Hengerer B, Masiakowski $\mathrm{P}$, Thoenen $\mathrm{H}$, Barde YA (1989) Molecular cloning and expression of brain-derived neurotrophic factor. Nature 341:149-152.

Levi-Montalcini R (1987) The nerve growth factor: thirty-five years later. Biosci Rep 7:681-699.

Lindsay RM, Alderson RF, Friedman B, Hyman C, Ip NY, Furth ME, Maisonpierre PC, Squinto SP, Yancopoulos GD (1991) The neurotrophin family of NGF-related neurotrophic factors. Rest Neurol Neurosci 2:211-220.
Lynch G, Smith RL, Mensah P, Cotman C (1973) Tracing the dentate gyrus mossy fiber system with horseradish peroxidase histochemistry. Exp Neurol 40:516-524.

Maisonpierre PC, Belluscio L, Squinto S, Ip NY, Furth ME, Lindsay RM, Yancopoulos GD (1990) Neurotrophin-3: a neurotrophic factor related to NGF and BDNF. Science 1446-1451.

Mattson M (1989) Cellular signaling mechanisms common to the development and degeneration of neuroarchitecture. A review. Mech Ageing Dev 50:103-157.

Middlemas DS, Lindberg RA, Hunter T (1991) trkB, a neural receptor protein-tyrosine kinase: evidence for a full-length and two truncated receptors. Mol Cell Biol 11:143-153.

Monaghan DT, Holets VR, Toy DW, Cotman CW (1983) Anatomical distributions of four pharmacologically distinct ${ }^{3} \mathrm{H}$-L-glutamate binding sites. Nature 306:176-179.

Nadler JV, Perry BW, Cotman CW (1978) Intraventricular kainic acid preferentially destroys hippocampal pyramidal cells. Nature 271:676677.

Nadler JV, Perry BW, Gentry C, Cotman CW (1981) Fate of the hippocampal mossy fiber projection after destruction of its postsynaptic targets with intraventricular kainic acid. J Comp Neurol 196: $549-569$.

Olney JW, Fuller T, DeGubareff T (1979) Acute dendrotoxic changes in the hippocampus of kainate treated rats. Brain Res 176:91-100.

Patterson SL, Grover LM, Schwartzkroin PA, Bothwell M (1992) Neurotrophin expression in rat hippocampal slices: a stimulus paradigm inducing LTP in CA1 evokes increases in BDNF and NT3 mRNAs. Neuron 9:1081-1088.

Phillips HS, Hains JM, Laramee GR, Rosenthal A, Winslow JW (1990) Widespread expression of BDNF but not NT3 by target areas of basal forebrain cholinergic neurons. Science 250:290-294.

Phillips HS, Hains JM, Armanini M, Laramee GR, Johnson SA, Winslow JW (1991) BDNF mRNA is decreased in the hippocampus of individuals with Alzheimer's disease. Neuron 7:695-702.

Radcke MJ, Misko TP, Hsu C, Herzenberg LA, Shootcr EM (1987) Gene transfer and molecular cloning of the rat nerve growth factor receptor. Nature 325:593-597.

Represa A, Tremblay E, Ben-Ari Y (1987) Kainate binding in the hippocampal mossy fibers: localization and plasticity. Neuroscience 20:739-748.

Robertson JH, Deadwyler SA (1981) Kainic acid produces depolarization of CA3 pyramidal cells in the in vitro hippocampal slice. Brain Res 221:117-127.

Rosenthal A, Goeddel DV, Nguyen T, Lewis M, Shih A, Laramee GR, Nikolics K, Winslow JW (1990) Primary structure and biological activity of a novel human neurotrophic factor. Neuron 4:767-773.

Shepherd GM (1979) The synaptic organization of the brain, 2d ed. New York: Oxford UP.

Simon RP, Swan JH, Griffiths T, Meldrum BS (1984) Blockade of $N$-methyl-D-aspartate receptors may protect against ischemic damage in the brain. Science 226:850-852.

Soppet D, Escandon E, Maragos J, Middlemas DS, Reid SW, Blair J, Burton LE, Stanton BR, Kaplan DR, Hunter T, Nikolics K, Parada LF (1991) The neurotrophic factors brain-derived neurotrophic factor and neurotrophin-3 are ligands for the trkB tyrosine kinase receptor. Cell 65:895-903.

Sperk G, Lassmann H, Baran H, Kish SJ, Seitelberger F, Hornykiewicz O (1983) Kainic acid induced seizures: neurochemical and histopathological changes. Neuroscience 10:1301-1315.

Squinto SP, Stitt TN, Aldrich TH, Davis S, Bianco SM, Radziejewski C, Glass DJ, Masiakowski P, Furth ME, Valenzuela DM, DiStephano PS, Yancopoulos GD (1991) trkB encodes a functional receptor for brain-derived neurotrophic factor and neurotrophin-3 but not nerve growth factor. Cell 65:885-893.

Strömberg I, Wetmore CJ, Ebendal T, Ernfors P, Persson H, Olson L (1990) Rescue of basal forebrain cholinergic neurons after implantation of genetically modified cells producing recombinant NGF. $\mathbf{J}$ Neurosci Res 25:405-411.

Sutula T, Cascino G, Cavazos J, Parada 1, Ramirez L (1989) Mossy fiber synaptic reorganization in the epileptic human temporal lobe. Ann Neurol 26:321-330.

Taniuchi M, Schweitzer JB, Johnson EJ (1986) Nerve growth factor receptor molecules in rat brain. Proc Natl Acad Sci USA 83:19501954.

Thoenen $\mathrm{H}$ (1991) The changing scene of neurotrophic factors. Trends Neurosci 14:165-170. 
Thoenen H, Barde YA (1980) Physiology of nerve growth factor. Physiol Rev 60:1284-1335.

Timmusk T, Palm K, Metsis M, Reintam T, Paalme V, Saarma M, Persson H (1993) Multiple promoters direct tissue-specific expression of the rat BDNF gene. Neuron 10:475-489.

Wainer BH (1989) Neurotrophic factors and Alzheimer's disease. Neurobiol Aging 10:540-542.

Watkins JC, Evans RH (1981) Excitatory amino acid transmitters Annu Rev Pharmacol Toxicol 21:165-204.

Watkins JC, Krogsgaard LP, Honoré T (1990) Structure-activity relationships in the development of excitatory amino acid receptor agonists and competitive antagonists. Trends Pharmacol Sci 11:2533.

Wetmore C, Ernfors P, Persson H, Olson L (1990) Localization of brain-derived neurotrophic factor mRNA to neurons in the brain by in situ hybridization. Exp Neurol 109:141-152.

Wetmore C, Cao Y, Pettersson RF, Olson L (1991) Brain-derived neurotrophic factor: subcellular compartmentalization and interneuronal transfer as visualized with anti-peptide antibodies. Proc Natl Acad Sci USA 88:9843-9847.

Wetmore C, Cao Y, Pettersson R, Olson L (1993) Brain-derived neurotrophic factor (BDNF) peptide antibodies: characterization using a vaccinia virus expression system. J Histochem Cytochem 41:521533.

Whittemore SR, Friedman PL, Larhammar D, Persson H, Gonzalez CM, Holets VR (1988) Rat beta-nerve growth factor sequence and site of synthesis in the adult hippocampus. J Neurosci Res 20:403410.

Wieloch T (1985) Hypoglycemia-induced neuronal damage prevented by an $N$-methyl-D-aspartate antagonist. Science 230:681-683.

Williams LR, Varon S, Peterson GF, Wictorin K, Björklund A, Gage FH (1986) Continuous infusion of nerve growth factor prevents basal forebrain neuronal death after fimbria fornix transection. Proc Natl Acad Sci USA 83:9231-9235

Zafra F, Hengerer B, Leibrock J, Thoenen H, Lindholm D (1990) Activity dependent regulation of BDNF and NGF mRNAs in the rat hippocampus is mediated by non-NMDA glutamate receptors. EMBO J 9:3545-3550.

Zafra F, Castren E, Thoenen H, Lindholm D (1991) Interplay between glutamate and gamma-aminobutyric acid transmitter systems in the physiological regulation of brain-derived neurotrophic factor and nerve growth factor synthesis in hippocampal neurons. Proc Natl Acad Sci USA 88:10037-10041. 